POEF-TS-02

LO CKHEED MARTIN

PORTSMOUTH GASEOUS DIFFUSION PLANT

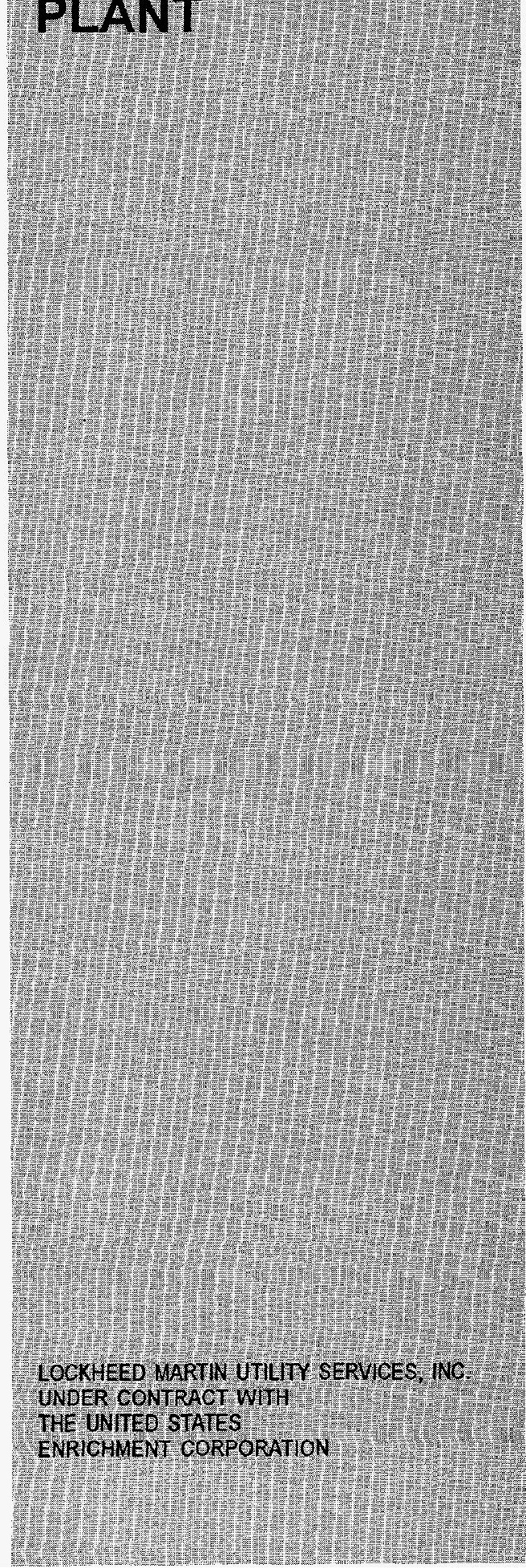

RECEIVED OCT 10 SS OSTI

Review of Corrosion in 10- and 14-Ton Mild Steel Depleted UF 6 Storage Cylinders

\author{
By \\ Michael L. Lykins
}

August 1995 
This report has been reproduced directly from the best available copy.

Available to DOE and DOE contractors from the Office of Scientific and Technical Information, P. O. Box 62, Oak Ridge, TN 37831; prices available from (615) 576-8401, FTS 626-8401.

Available to the public from the National Technical Information Service, U.S. Department of Commerce, 5285 Port Royal Rd., Springfield, VA 22161.

This report was prepared as an account of work sponsored by an agency of the United States Government. Neither the United States Government nor any agency thereof, nor any of their employees, makes any warranty, express or implied, or assumes any legal liability or responsibility for the accuracy, completeness, or usefulness of any information, apparatus, product, or process disclosed, or represents that its use would not infringe privately owned rights. Reference herein to any specific commercial product, process, or service by trade name, trademark, manufacturer, or otherwise, does not necessarily constitute or imply its endorsement, recommendation, or favoring by the United States Government or any agency thereof. The views and opinions of authors expressed herein do not necessarily state or reflect those of the United States Government or any agency thereof. 


\section{DISCLAIMER}

Portions of this document may be illegible in electronic image products. Images are produced from the best available original document. 


\title{
REVIEW OF CORROSION IN 10- AND 14-TON MILD STEEL DEPLETED UF 6 STORAGE CYLINDERS
}

By

Michael L. Lykins

August 1995

\author{
LOCKHEED MARTIN UTILITY SERVICES, INC. \\ Portsmouth Gaseous Diffusion Plant \\ P.O. Box 628 Piketon, Ohio 45661 \\ Under Contract USECHQ-93-C-0001 \\ to the \\ UNITED STATES ENRICHMENT CORPORATION
}


Blank Page 
MARTIN MARIETTA UTILITY SERVICES, INC.

Portsmouth GDP

DISTRIBUTION

Paducah Gaseous Diffusion Plant

S. C. Blue

W. Stokes

\section{Oak Ridge}

J. A. Horak

D. L. Mason

V. S. Newman

S. J. Pawel

H. E. Philpot

M. A. Schmidt

M. S. Taylor

D. F. Wilson

Portsmouth Gaseous Diffusion Plant

G. E. Bobo

R. A. Boelens

R. D. Bussa

S. L. Fout

C. F. Harley

M. Jermusyk

T. M. Marshall

R. M. Nolfi

A. J. Saraceno

T. D. Taylor

H. H. Thomas

D. W. Thompson

D/38-343 File

Central Files (2)

Technical Library

Technical Review (2) 
Blank Page 


\section{TABLE OF CONTENTS}

EXECUTIVE SUMMARY $\ldots \ldots \ldots \ldots \ldots \ldots \ldots \ldots \ldots \ldots$

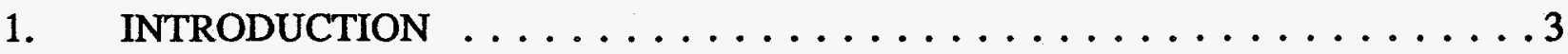

2. TYPES OF CORROSION IN THE 10- AND 14-TON MILD STEEL DEPLETED UF STORAGE CYLINDERS $\ldots \ldots \ldots \ldots \ldots \ldots \ldots \ldots \ldots \ldots \ldots \ldots \ldots \ldots$

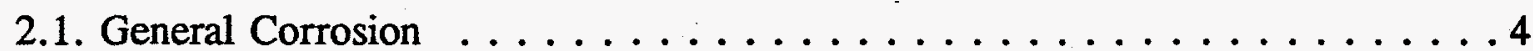

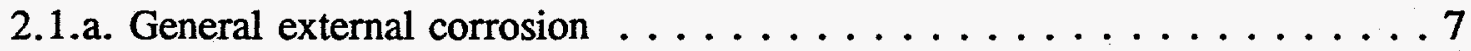

2.1.a.1. Ultrasonic thickness (UT) data . . . . . . . . . . . 7

2.1.a.2. Painting of mild steel depleted $\mathrm{UF}_{6}$ storage cylinders $\ldots \ldots \ldots 7$

2.1.b. General internal corrosion by depleted $\mathrm{UF}_{6} \ldots \ldots \ldots \ldots$

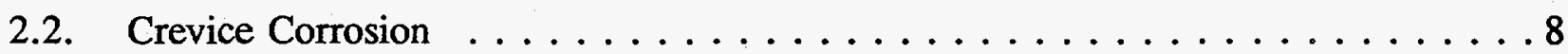

2.2.a. Cylinder support saddles $\ldots \ldots \ldots \ldots \ldots \ldots \ldots$

2.2.b. Cylinder skirts . . . . . . . . . . . . . . . .99

2.2.c. Cylinders in ground contact $\ldots \ldots \ldots \ldots \ldots \ldots \ldots$

2.2.d. Stainless steel cylinder identification nameplates . . . . . . . . 10

2.2.e. Bronze valves and plugs $\ldots \ldots \ldots \ldots \ldots \ldots \ldots \ldots$

2.3. Galvanic Corrosion . . . . . . . . . . . . . . . . . . 11

2.3.a. 10- and 14-ton mild steel storage cylinders ... . . . . . . 12

2.3.b. Stainless steel cylinder identification nameplates . . . . . . . 12

2.3.c. Tinning of the threads on the valves and plugs . . . . . . . . 12

2.3.d. Bronze valves and plugs $\ldots \ldots \ldots \ldots \ldots \ldots \ldots$

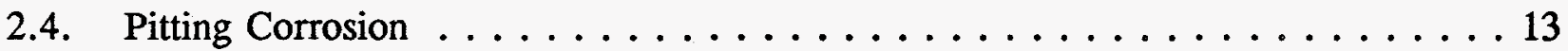

2.5. Stress Corrosion Cracking $\ldots \ldots \ldots \ldots \ldots \ldots \ldots \ldots \ldots \ldots \ldots$

2.5.a. Packing (Bonnet) nuts . . . . . . . . . . . . 14

2.6. Mechanical Damage ... . . . . . . . . . . . . . . . 15

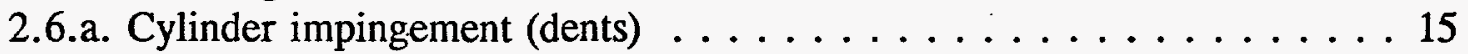

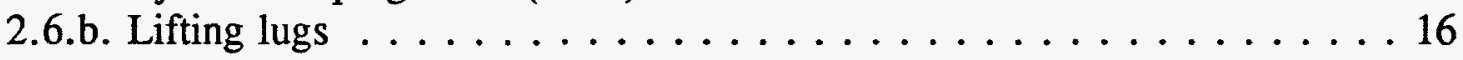

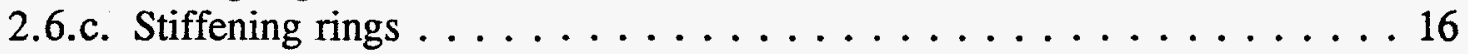

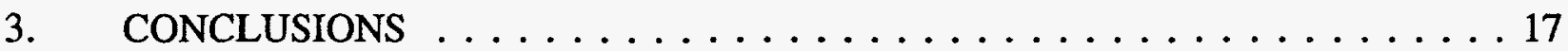

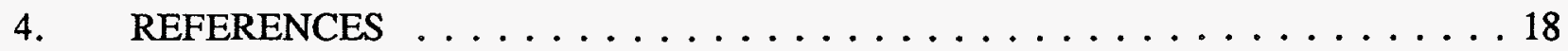


Blank Page 


\section{EXECUTIVE SUMMARY}

A literature review was conducted to determine the type, extent and severity of corrosion found in the 10- and 14-ton mild steel depleted $\mathrm{UF}_{6}$ storage cylinders. Also discussed in this review is corrosion found in the valves and plugs used in the cylinders. Corrosion of the cylinders is a gradual process which occurs slowly over time. Understanding corrosion of the cylinders is an important concern for long term storage of the $\mathrm{UF}_{6}$ in the cylinder yards, as well as the final disposition of the depleted $\mathrm{UF}_{6}$ tails inventory in the future.

The following conclusions are made from the literature review:

- The general external corrosion rate of the cylinders is about 1 to 2 mils per year (1 mil $=0.001 ")$. The highest general external corrosion rate was over $5 \mathrm{mpy}$ on the 48G type cylinders.

- General internal corrosion from the depleted $\mathrm{UF}_{6}$ is negligible under normal storage conditions.

Crevice corrosion can occur at the cylinder/saddle interface from the retention of water in this area.

- Crevice corrosion can occur at the cylinder/skirt interface on the older skirted cylinders due to the lack of water drainage in this area.

Crevice corrosion can occur on cylinders that have been in ground contact.

Crevice corrosion and galvanic corrosion can occur where the stainless steel I.D. nameplates are attached to the cylinder.

The packing nuts on the bronze one-inch valves used in the cylinders are susceptible to stress corrosion cracking (SCC).

Mechanical damage from routine handling can lead to a breach in a cylinder with subsequent accelerated corrosion of the mild steel due to attack from HF and other $\mathrm{UF}_{6}$ hydrolysis by-products. 


\section{Blank Page}




\section{INTRODUCTION}

There are currently more than 44,000 10- and 14-ton mild steel storage cylinders containing depleted uranium hexafluoride $\left(\mathrm{UF}_{6}\right)$ stored at the $\mathrm{K}-25$ site in Oak Ridge, Tennessee and at the uranium enrichment facilities at Portsmouth, Ohio and Paducah, Kentucky. Some of the cylinders have been in storage for over 40 years. The original 10-ton storage cylinders were fabricated from A285 mild steel with an initial wall thickness of $0.625^{\prime \prime}$ or $5 / 8^{\prime \prime}$ (thick wall cylinder). The original design of the cylinders has been modified several times.

The current design of the 14-ton storage cylinders specifies A516 mild steel with a wall thickness of $0.325^{\prime \prime}$ or $5 / 16^{\prime \prime}$ (thin wall cylinder). The wall thickness was reduced because the thick wall cylinder had been designed conservatively for outside storage of the depleted $\mathrm{UF}_{6}{ }^{1}$ The change in mild steel alloys was based on the increased fracture toughness of A516 mild steel at low temperatures. ${ }^{2}$ The fracture toughness specifications for the A516 mild steel used in the cylinders are specified in ANSI N14.1.3 There were no fracture toughness specifications for cylinders fabricated with A285 steel. Table 1 lists the types for the 10- and 14-ton mild steel cylinders stored at the three sites.

The minimum thickness specifications for the 10- and 14-ton mild steel storage cylinders are based currently on the ANSI N14.1 standards for shipping and heating of depleted UF $_{6 .}{ }^{3}$ The current acceptable minimum wall thickness limits are $0.500^{\prime \prime}$ for thick wall and $0.250^{\prime \prime}$ for thin wall cylinders. ${ }^{3}$ The storage cylinders are currently fabricated according to the ASME Boiler and Pressure Vessel Code, Section VIII, Division 1 and supplied with the Manufacturer's Data Report, ASME Code Form U-1 or U-1A. ${ }^{4}$

To date, there is no accepted plan to remove, or a developed method to recover, the depleted $\mathrm{UF}_{6}$ tails stored in the cylinders. It is anticipated that early in the next century, a conversion process will be developed, such that the depleted $\mathrm{UF}_{6}$ may be converted into a more stable compound for permanent disposition. ${ }^{5}$ Therefore, it is important that the corrosion characteristics of the cylinders be evaluated and known, to ensure safe storage of the depleted $\mathrm{UF}_{6}$ until a conversion process is developed.

Corrosion of the mild steel cylinders can be monitored and controlled. General external corrosion is typically slow and life expectancy calculations may be developed over time. However, other forms of corrosion may proceed more rapidly and could lead eventually to a breach in a cylinder. This report reviews the various types of corrosion that may be found in the 10- and 14-ton mild steel storage cylinders. Corrosion of the valves and plugs used in the cylinders are also discussed in this report. 
Table 1: 10- And 14-Ton Mild Steel Depleted UF 6 Storage Cylinders

\begin{tabular}{|c|c|c|c|c|}
\hline CYMTIEER & (tons) & $\begin{array}{l}\text { ORIGINAI } \\
\text { THICKNESS }\end{array}$ & TYPE OF & MANUPACTURED \\
\hline $48 \mathrm{~A}$ & 10 & $5 / 8^{n}$ & A285 & $1953-54$ \\
\hline $48 \mathrm{X}$ & 10 & $5 / 8^{n}$ & A285 & $1953-54$ \\
\hline $48 \mathrm{~T}(48 \mathrm{~B})$ & 10 & $5 / 16^{n}$ & A285 & $1956-58$ \\
\hline 480 & 14 & $5 / 16^{\prime \prime}$ & A285 & $1959-61$ \\
\hline $48 \mathrm{~F}$ & 14 & $5 / 8^{\prime \prime}$ & A285. & $1961-1962$ \\
\hline $48 \mathrm{OH}$ & 14 & $5 / 8^{\prime \prime}$ & A285 & 1962 \\
\hline $48 \mathrm{OHI}$ & 14 & $5 / 8^{\prime \prime}$ & A285 & $1962-1963$ \\
\hline $480 \mathrm{M}$ & 14 & $5 / 16^{n}$ & A285 & $1962-78$ \\
\hline $48 \mathrm{H}$ & 14 & $5 / 16^{n}$ & A285 & $1979-83$ \\
\hline $48 \mathrm{HX}$ & 14 & $5 / 16^{\prime \prime}$ & A285 & 1979 \\
\hline $48 Y$ & 14 & $5 / 8^{\prime \prime}$ & A516 & $1979-80$ \\
\hline $48 G$ & 14 & $5 / 16^{n}$ & A516 & 1978-PRESENT \\
\hline
\end{tabular}

\section{TYPES OF CORROSION IN THE 10-AND 14-TON MILD STEEL DEPLETED UF $_{6}$ STORAGE CYLINDERS}

Corrosion can be defined as the destruction or deterioration of a material caused by a chemical reaction with its environment. ${ }^{6-8}$ There are several types of corrosion which may be occurring in the 10- and 14-ton mild steel depleted $\mathrm{UF}_{6}$ storage cylinders, including general corrosion, crevice corrosion, galvanic corrosion, pitting corrosion and stress corrosion cracking. A brief description of mechanical damage to the cylinders is also discussed. An overview of these corrosion mechanisms and their significance is summarized in Table 2. A discussion and an evaluation of the information on corrosion of the storage cylinders is detailed below.

\subsection{General Corrosion}

General (uniform) corrosion will gradually reduce the metal thickness of a component over time and typically proceeds uniformly over the exposed metal surface. ${ }^{7,8}$ It is a preferable type of corrosion for engineering design because life expectancy calculations can be determined. There are two types of general corrosion to be considered in the mild steel depleted $\mathrm{UF}_{6}$ storage cylinders, external corrosion from the atmosphere and internal corrosion due to the depleted $\mathrm{UF}_{6}$. 
Table 2: TYPES OF CORROSION IN THE 10-AND 14-TON DEPLETED UF 6 MILD STEEL STORAGE CYLINDERS

\begin{tabular}{|c|c|c|c|c|c|c|}
\hline IOCATION ON CYUINDER & $\begin{array}{l}\text { GENERAL } \\
\text { CORROSION }\end{array}$ & $\begin{array}{l}\text { CREVICE } \\
\text { CORROSION }\end{array}$ & GAYVRNIC, & CORROSION & $\begin{array}{l}\text { STRESS } \\
\text { CORROSION } \\
\text { CRTCKING. }\end{array}$ & $\begin{array}{l}\text { PDOMIONAI } \\
\text { COMMENTS }\end{array}$ \\
\hline Body of cylinder (exterior). & About 1 to 2 mpy. ${ }^{1,9,10}$ & N/A & N/A & N/A & N/A & \\
\hline Shell interior. & $\begin{array}{l}\text { Less than about } 0.1 \\
\text { mpy. }{ }^{13}\end{array}$ & N/A & N/A & N/A & N/A & \\
\hline Cylinder/saddle interface. & N/A & $\begin{array}{l}\text { Higher corrosion rate } \\
\text { when water is } \\
\text { retained. }{ }^{11,14,15}\end{array}$ & N/A & $\begin{array}{l}\text { Higher corrosion } \\
\text { rate. }{ }^{11,14,15}\end{array}$ & N/A & \\
\hline Cylinder/skirt interface. & N/A & $\begin{array}{l}\text { Higher corrosion } \\
\text { rate. }{ }^{16,17}\end{array}$ & N/A & $\begin{array}{l}\text { Higher corrosion } \\
\text { rate. }^{16,17}\end{array}$ & N/A & \\
\hline Cylinder/ground contact. & N/A & $\begin{array}{l}\text { Higher corrosion } \\
\text { rate. }{ }^{14,18}\end{array}$ & N/A & $\begin{array}{l}\text { Higher corrosion } \\
\text { rate. }^{14,18}\end{array}$ & N/A & \\
\hline Stainless steel I.D. nameplates. & N/A & $\begin{array}{l}\text { Higher corrosion } \\
\text { rate. }^{2,18}\end{array}$ & $\begin{array}{l}\text { Causes the } \\
\text { detachment of } \\
\text { nameplates. }^{2}\end{array}$ & N/A & $N / A$ & \\
\hline
\end{tabular}


Table 2: TYPES OF CORROSION IN THE 10-AND 14-TON DEPLETED UF 6 MILD STEEL STORAGE CYLINDERS (continued)

\begin{tabular}{|c|c|c|c|c|c|c|}
\hline LOCATION ON CYLINDER & $\begin{array}{l}\text { GENERAL, } \\
\text { CORROSION }\end{array}$ & $\begin{array}{l}\text { CREVICE. } \\
\text { CORROSION }\end{array}$ & $\begin{array}{l}\text { GALVANIC } \\
\text { CORROSION }\end{array}$ & $\begin{array}{l}\text { PITTING } \\
\text { CORROSION }\end{array}$ & $\begin{array}{l}\text { STRESS } \\
\text { CORROSION } \\
\text { CRACKING }\end{array}$ & ADDITIONAI \\
\hline $\begin{array}{l}\text { Bronze valve and plug in mild steel } \\
\text { cylinder. }\end{array}$ & N/A & Not reported to date. & $\begin{array}{l}\text { Not reported } \\
\text { to date. }\end{array}$ & N/A & $\begin{array}{c}\text { Occurs on } \\
\text { bonnet nuts. }{ }^{20-25}\end{array}$ & \\
\hline $\begin{array}{l}\text { Tinning of bronze threads on valves } \\
\text { and plugs. }\end{array}$ & N/A & N/A & $\begin{array}{l}\text { Not reported } \\
\text { to date. }\end{array}$ & N/A & N/A & $\begin{array}{l}\text { Can cause liquid metal } \\
\text { embrittlement in } \\
\text { valves. }{ }^{22}\end{array}$ \\
\hline Cylinder impingement (dents). & N/A & N/A & N/A & N/A & N/A & $\begin{array}{l}\text { Damage from routine } \\
\text { handling may lead to } \\
\text { breaches. } 214,28\end{array}$ \\
\hline Lifting lugs. & N/A & N/A & N/A & N/A & N/A & $\begin{array}{c}\text { Cracks caused by } \\
\text { fabrication defects. }\end{array}$ \\
\hline Stiffening rings. & N/A & $\begin{array}{l}\text { Amount not known on } \\
480 \text { type cylinders. }\end{array}$ & N/A & N/A & N/A & $\begin{array}{l}\text { Damage from routine } \\
\text { handling may lead to } \\
\text { breaches. }{ }^{2} 14,28\end{array}$ \\
\hline $\begin{array}{l}\text { Welds for shell to heads, skirts and } \\
\text { stiffening rings . }\end{array}$ & $\mathrm{N} / \mathrm{A}$ & $\mathrm{N} / \mathrm{A}$ & N/A & N/A & N/A & $\begin{array}{l}\text { Damage from routine } \\
\text { handling may lead to } \\
\text { breaches. }\end{array}$ \\
\hline
\end{tabular}




\section{1.a. General external corrosion}

The mild steel depleted $\mathrm{UF}_{6}$ storage cylinders experience general external corrosion. The cylinders were painted originally after fabrication to improve the appearance which provided a protective barrier to reduce the external corrosion of the mild steel. However, routine cylinder handling and autoclave cycles have caused degradation of the paint used on the cylinders.

The reduction in the wall thickness from general external corrosion can be calculated from ultrasonic thickness (UT) measurements conducted on the cylinders. The corrosion of mild steel can also be simulated by controlled comparative tests (corrosion coupons and atmospheric corrosion probes). Based on this information, corrosion rates and remaining life expectancies can be approximated for the mild steel depleted $\mathrm{UF}_{6}$ storage cylinders.

\section{1.a.1. Ultrasonic thickness (UT) data}

Hand-held UT measurements have been conducted on more than 170 10- and 14-ton mild steel depleted $\mathrm{UF}_{6}$ storage cylinders at PORTS. ${ }^{9}$ The UT data have shown that general external corrosion rates vary from less than 1 mil per year (mpy) to more than 5 mpy $(1 \mathrm{mil}=0.001 ") .^{9}$ In general, the external corrosion rate of the cylinders was between 1 and 2 mpy. The corrosion rates calculated from results at PORTS were similar to the $1.6 \mathrm{mpy}$ and 2 mpy corrosion rates calculated from UT measurements of depleted $\mathrm{UF}_{6}$ storage cylinders at PDGP in 1974 and 1988, respectively. ${ }^{1,10}$ It should be noted that an atmospheric corrosion rate between 1 and 5 mpy for ferrous materials is considered excellent. ${ }^{7}$

The highest general external corrosion rates determined from the UT measurements at PORTS were for the 48G type 14-ton mild steel storage cylinders. ${ }^{9}$ The $48 \mathrm{G}$ and the $480 \mathrm{M}$ type cylinders are both thin walled cylinders. The outer surface of the 48G type cylinders are grit blasted before being painted, whereas the 480M type cylinders were not grit blasted. The higher corrosion rate found with the 48G type cylinders $^{9}$ may be the result of grit blasting prior to the painting (Section 2.1.a.2.).

\section{1.a.2. Painting of mild steel depleted $U F_{6}$ storage cylinders}

All of the 10- and 14-ton mild steel depleted $\mathrm{UF}_{6}$ storage cylinders are painted after fabrication. The paint protects the mild steel from corrosion until the paint is damaged or removed accidentally. According to corrosion textbooks, ${ }^{7,8}$ grit (sand) blasting prior to the paint application is the desired type of procedure for preventing the onset of corrosion.

The current $48 \mathrm{G}$ type mild steel cylinders were grit blasted after fabrication. The cylinders are then painted. A laboratory study was conducted at K-25 to evaluate the corrosion characteristics of mild steel in contact with wood and concrete used to support the cylinders. ${ }^{11}$ Concrete was found to be equal to and/or better than wood as the material for the saddle supports (chocks) used to support the cylinders. In addition to these results, a mild steel surface with a glass bead blasted finish was 
found to corrode at a much faster rate than an oxidized or polished steel surface. ${ }^{11}$ This may suggest that the mild steel cylinders which have been grit (or sand) blasted prior to painting ( $48 \mathrm{G}$ type cylinders), may corrode more rapidly when the paint layer is removed than the older cylinder types (ie. 48OM type cylinders), which received no such surface preparation. Without this surface preparation, the steel would have mill scale on the surface.

A study conducted on coating alternatives for refurbishing the old mild steel storage cylinders recommended an abrasive blast cleaning of the metal surface. ${ }^{12}$ A number of cylinders were sand blasted and painted in 1979 for shipment to Italy. Some of those cylinders were not shipped to Italy due to a small defect in the appearance of the cylinder, such as a dent. The paint on the top and bottom of the "Italian" cylinders have started to deteriorate. The paint on the body of the cylinder is in good condition. These "Italian" cylinders tend to show how long paint can last on a properly prepared steel surface.

\section{1.b. General internal corrosion by depleted $\mathrm{UF}_{6}$}

General internal corrosion in the 10- and 14-ton mild steel cylinders by depleted $\mathrm{UF}_{6}$ in the solid state has been previously examined and was considered to be a form of general corrosion. ${ }^{2,13}$ "The time required to penetrate the $5 / 16$-in wall of a $\mathrm{UF}_{6}$ storage cylinder at $70^{\circ} \mathrm{C}\left(158^{\circ} \mathrm{F}\right)$ (assumed to be the maximum temperature experienced by such a cylinder when exposed to direct rays of the sun) is on the order of a million years. "13 Under normal storage conditions, general internal corrosion from the depleted $\mathrm{UF}_{6}$ is not a significant problem for the 10 - and 14-ton mild steel depleted UF $_{6}$ storage cylinders.

When a cylinder is breached, corrosion of the mild steel storage cylinder may occur quite rapidly. The $\mathrm{UF}_{6}$ reacts in the presence of water to form HF. The HF and other $\mathrm{UF}_{6}$ hydrolysis by-products will accelerate the corrosion of the mild steel cylinder at the breached area. The corrosion products that form as a result of the breach act as a selfsealing patch on the cylinder. ${ }^{2}$ This is a unique incident where accelerated corrosion may occur as a result of mechanical damage or through wall thickness corrosion.

\subsection{Crevice Corrosion}

Crevice corrosion is localized corrosion on metal surfaces which are exposed to small volumes of a stagnant solution. ${ }^{6,7}$ Crevice corrosion is the result of differential aeration, where the supply of oxygen by diffusion is greater in the crevice than outside the crevice. ${ }^{6}$ Crevice corrosion may occur in contact areas between metal and nonmetallic surfaces, such as wood, rubber and concrete. 
Crevice corrosion can be found where the mild steel cylinder rests in the cylinder support saddles to due the retention of water. Crevice corrosion occurs at the cylinder/skirt interface on the older cylinders due to poor water drainage. Crevice corrosion occurs on cylinders that are stored in contact with the ground. The stainless steel identification (I.D.) nameplates and the threaded regions of the bronze valves in the cylinders, may also provide a location for crevice corrosion.

\section{2.a. Cylinder support saddles}

A laboratory study was conducted at $\mathrm{K}-25$ to evaluate the corrosion characteristics of mild steel due to contact with wood and concrete. ${ }^{11}$ The accelerated immersion test results showed that mild steel in contact with concrete does not corrode more rapidly than mild steel in contact with wood. The corrosion rate for the steel/concrete interface ranged from 1.7 to $5.6 \mathrm{mpy}$, depending on the surface condition of the steel prior to testing. ${ }^{11}$

UT measurements of randomly selected cylinder walls at K-25 found that metal losses greater than 0.125 " (125 mils) were present at the bottom of the cylinders. ${ }^{14}$

A non-destructive evaluation on a number of depleted $\mathrm{UF}_{6}$ mild steel storage cylinders has been conducted recently at $\mathrm{K}-25^{15}$ and at PGDP. The evaluation at both sites used a P-Scan UT measurement technique. The UT program was developed to determine the condition of the bottom of selected cylinders known to have been in ground contact, as well as cylinders stored under normal storage conditions. At K-25, the UT measurements were conducted adjacent to the support saddle. At PGDP, the cylinders were relocated temporarily to a staging area. The support saddles were moved such that measurements along the cylinder/saddle interface could be obtained. The wall thickness and pit depth measurements were obtained during the measurement program.

Initial results of the study at K-25 on 136 mild steel depleted $\mathrm{UF}_{6}$ storage cylinders have shown that the cylinders stored in the support saddles experience crevice corrosion, near the cylinder/saddle interface. The wall thickness at this interface was found to range from $0.140^{\text {" }}$ to $0.300^{\mathrm{N}} .{ }^{15}$ The accelerated corrosion may be the result of retained water at the cylinder/saddle interface and/or due to poor water drainage in the storage yards. To date, a report of the results for the UT measurement program at PGDP was not available. However, crevice corrosion was found along the cylinder/saddle interface, as well as on the cylinders that had been in ground contact.

\section{2.b. Cylinder skirts}

The majority of the 10- and 14-ton mild steel storage cylinders do not have a skirt, but use a valve end protector, including the current $48 \mathrm{G}$ type cylinders. However, crevice 
corrosion is also found at the cylinder/skirt interface on the older mild steel depleted $\mathrm{UF}_{6}$ storage cylinders. The design of the mild steel protective skirt had a small hole at the 6 o'clock position for water drainage, assuming the valve to be at the 12 o'clock position.

Previous handling procedures did not provide the controls necessary to ensure that the cylinders were placed with the drain hole at the $60^{\prime}$ 'clock position. Therefore, many of the drain holes have been ineffective in draining water from this area. In addition to the misalignment of the cylinders for proper water drainage, debris has plugged many of the drain holes which were stacked properly. Water and moisture have remained in the cylinder/skirt interface, causing accelerated corrosion. A study of two 14-ton cylinders at PORTS in 1992 found 60 to 80 mils of metal loss had occurred on the outside of the skirt near the cylinder/skirt interface. ${ }^{16}$

A study was conducted at K-25 to evaluate corrosion at the cylinder/skirt interface using metallographic replicas. ${ }^{17}$ The replicas were used to characterize corrosion and pitting of the cylinder/skirt interface at the 6 o'clock position. Pit depths up to 150 mils were found at the interface on one cylinder. ${ }^{17}$ Also reported were the results of UT measurements with a small diameter "pencil" probe at the cylinder/skirt interface. A minimum wall thickness of $0.200^{\prime \prime}$ was measured on two cylinders at about two inches from the cylinder/skirt interface. ${ }^{17}$

\section{2.c. Cylinders in ground contact}

A study conducted at $\mathrm{K}-25$ to examine four breached cylinders found that ground contact of a breached cylinder (Cylinder 101244) may have caused its failure by "differential oxygenation corrosion." 14 This may be considered a form of crevice corrosion. The failed area of the cylinder may have been in ground contact for an unknown period of time. Moisture in the ground will increase corrosion of the steel that is in ground contact.

A study conducted at $\mathrm{K}-25$ found the corrosion rate of mild steel samples in ground contact after six months had a corrosion rate between 1.5 and 5.5 mpy ${ }^{18}$ The samples were pitted, with a pit depth of up to about 11 mils. ${ }^{18}$ The controlled study tends to show how accelerated corrosion occurs on mild steel samples in ground contact.

\section{2.d. Stainless steel cylinder identification nameplates}

The identification (I.D.) nameplates used on the 10- and 14-ton mild steel storage cylinders are made of stainless steel. The I.D. nameplates on the older cylinders are tack welded at the four corners. The I.D. nameplates used on the newer $48 \mathrm{G}$ type cylinders are welded around the circumference of the nameplate. Moisture and water can collect 
behind the I.D. nameplate on the older cylinders, causing crevice corrosion. It has been noted that these areas may experience more corrosion than on the body of the cylinder'.

A study was conducted at K-25 using metallographic replicas on three cylinders where the I.D. nameplate had been located, but was no longer attached to the cylinder. ${ }^{18}$ The results of the study found about 35 to 45 mils of accelerated corrosion in this area. ${ }^{18}$

The quantity of metal lost from the head of the depleted $\mathrm{UF}_{6}$ storage cylinders at this location should not be detrimental to the integrity of the cylinder.

\section{2.e. Bronze valves and plugs}

The bronze valves and plugs used in the mild steel depleted $\mathrm{UF}_{6}$ storage cylinders may lead to crevice corrosion and/or galvanic corrosion. Moisture could enter between the threads of a cylinder and the valve (or plug) causing crevice corrosion. "Crevice corrosion occurring between threaded fittings and pipes is offset by the use of a compound in the joint or by the use of soldered fittings or by brazing, all of which prevent liquids from getting into the crevice. ${ }^{8}$ To date, crevice corrosion in this area has not been reported in the cylinders.

It is difficult to characterize and quantify crevice corrosion around the valves (or plugs) in the cylinders. A vacuum test on a cylinder may reveal a leaking valve or plug. However, the leak may be from the valve or plug itself and not necessarily caused by crevice corrosion around the threads of the valve or plug.

\subsection{Galvanic Corrosion}

Galvanic corrosion occurs when two dissimilar metals are electrically connected in the presence of a conductive or corrosive solution. ${ }^{7,8}$ The metal which is more active (anodic) will corrode preferentially to the more noble (cathodic) metal. To reduce the effects of galvanic corrosion, the active metal should be much larger in size than the noble metal. This provides a favorable area effect. A large anode may not eliminate the effects of the galvanic couple, but the amount of corrosion may be reduced due to the large anode.

The use of different alloys of mild steel in the 10- and 14-ton mild steel depleted UF $_{6}$ storage cylinders should have little, if any, galvanic effect. The use of stainless steel cylinder I.D. nameplates may lead to galvanic corrosion. The use of bronze alloys for the valve and plug in a cylinder may increase the susceptibility of galvanic corrosion.

Galvanic corrosion does not appear to have a significant effect on the integrity of the 10- and 14-ton mild steel depleted $\mathrm{UF}_{6}$ storage cylinders. 


\section{3.a. 10 - and 14-ton mild steel storage cylinders}

Galvanic corrosion does not appear to be a significant problem with the mild steel alloys used in the depleted $\mathrm{UF}_{6}$ storage cylinders. The mild steel used in the manufacturing of the cylinder shell, heads, stiffening rings, skirt and lifting lugs may have been A285 Grades A, B or C or A516 Grade 55,60,65 or 70. The mild steel used in the cylinders was changed from A285 to A516 in 1979. A36 or A131 mild steel may have been used for the stiffening rings. ${ }^{3}$

There are little differences in the chemical composition and electrochemical characteristics of the mild steel alloys used in the cylinders. Although there may have been some cylinders fabricated using various types and grades of steel, there should be no galvanic effects between the different steel alloys used in the cylinders.

\section{3.b. Stainless steel cylinder identification nameplates}

As mentioned above, the stainless steel I.D. nameplates on the older cylinders are tack welded at the four corners. The I.D. nameplates used on the newer 48G type cylinders are welded around the circumference of the nameplate. The use of stainless steel I.D. nameplates welded to the head of a cylinder creates an electrical connection between two dissimilar metals. The stainless steel is a more noble metal than the mild steel used for the cylinder. This can cause accelerated corrosion of the mild steel due to the galvanic couple in the presence of an electrolyte.

The loss of metal at the tack weld has resulted in the detachment of the I.D. nameplate from some of the cylinders. ${ }^{2}$ The large size of the mild steel cylinder (anode) provides a favorable area effect to the stainless steel, as mentioned above. As with crevice corrosion, galvanic corrosion from the I.D. nameplate should not create problems with the integrity of the cylinder. However, the detachment of the I.D. nameplate may create difficulties in cylinder monitoring and maintaining ASME Code status for the cylinder.

\section{3.c. Tinning of the threads on the valves and plugs}

The threads on the one-inch bronze valves and plugs used in the 10- and 14-ton mild steel depleted $\mathrm{UF}_{6}$ storage cylinders are tinned with a thin tin/lead coating. ${ }^{3}$ The type of solder used has changed over time. The solder used currently is a 50/50 tin/lead solder which meets ASTM B-32 Alloy 50A specifications. ${ }^{3}$ The solder used on the threads of the bronze valves and plugs are closely related in the galvanic series. ${ }^{7,8}$ There should be no galvanic effects under normal storage conditions. 
The tinning of the threads on the bronze valves and plugs have led to other types of failures, such as liquid metal embrittlement of the valves. Liquid metal penetrates the stressed material along the grain boundaries. The material than becomes susceptible to failure in this weakened area.

A one-inch valve used in a storage cylinder failed in 1985 by liquid metal embrittlement. ${ }^{19}$ Solder had penetrated the valve body. This type of failure has not occurred often in the one-inch valves and plugs used in the 10- and 14-ton mild steel storage cylinders.

\section{3.d. Bronze valves and plugs}

A galvanic couple is created between the mild steel cylinders and the bronze alloys used in the valve and plug. If moisture enters between the mild steel threads of the cylinder and the tinned bronze threads, the mild steel threads will suffer corrosion. Although a galvanic couple is present at this location, a favorable area ratio between the cylinder and the valve and plug may reduce the effects of galvanic corrosion, similar to that found at the cylinder I.D. nameplate (Section 2.3.b.).

To date, galvanic corrosion of the threads on a cylinder caused by the bronze valve or plug has not been reported in the 10- and 14-ton mild steel depleted $\mathrm{UF}_{6}$ storage cylinders.

\subsection{Pitting Corrosion}

Pitting corrosion is a form of localized attack that results in penetration into the metal..$^{6-8}$ Pits may be small or large. Pits can be isolated or close together, and are difficult to detect and measure. It is a very destructive type of corrosion.

A corrosion pit results from a unique type of an electrochemical reaction. ${ }^{7}$ For a pit to grow over time, the base of the pit is anodic and the sides of the pit are cathodic. If there were several pits on the metal surface, the pits may cathodically protect the rest of the metal surface.? Damage to the painted surface of the steel cylinder will initiate accelerated corrosion, which may develop into pitting corrosion. Breaks in the mill scale, which forms during the rolling operation, have been found to initiate pitting of mild steel in salt water. ${ }^{8}$

Pitting corrosion is very similar to crevice corrosion. ${ }^{7}$ All systems that have pitting are very susceptible to crevice corrosion. However, many systems that have crevice corrosion do not have pitting. Pitting may be a self-initiating form of crevice corrosion. It does not require a crevice, it creates its own. ${ }^{7}$ 
Pitting may be pronounced at the bottom, or resting surface, of the mild steel cylinders where the corrosion rate is high and the surface is often wet. A study at $\mathrm{K}-25$ found that pitting in the cylinders in the vicinity of the support saddles was less than $1 / 16^{\prime \prime}\left(0.0625^{\prime \prime}\right)$ deep. ${ }^{14}$ Metallographic replicas of the surface of corroded cylinders have shown the amount of pitting at the cylinder/skirt interface and where the I.D. nameplate had been located. ${ }^{17}$ The pit depth on one cylinder was found to be 150 mils (Section 2.2.b.). ${ }^{17}$

Pitting may be found along the cylinder/saddle interface, the cylinder/skirt interface, on cylinders in ground contact and behind the stainless steel I.D. nameplate on the cylinder. These areas have been discussed previously in Section 2.2. of this report. All of these locations behave as a crevice where accelerated corrosion occurs. Whether these areas are categorized as crevice corrosion or pitting corrosion, the primary importance is the identification of these areas as locations for accelerated corrosion in the 10- and 14-ton mild steel depleted $\mathrm{UF}_{6}$ storage cylinders.

\subsection{Stress Corrosion Cracking}

Stress corrosion cracking (SCC) refers to cracking in a material caused by the combination of a high tensile stress and a corrosive environment. ${ }^{6-8}$ The material in question must be susceptible to SCC in that particular environment. SCC is a delayed failure that may require months or years to become evident under normal storage conditions.

For instance, welding of mild steel components generates high internal stresses in the metal near the weld. If the mild steel was exposed to a corrosive environment, such as a carbonatebicarbonate or a caustic solution, mild steel would be susceptible to SCC. The amount of cracking tends to increase with increasing service temperature. To reduce the susceptibility of SCC in welded mild steel components, methods, such as post-weld stress relieving practices, are used to reduce the amount of internal stresses in the component.

To date, stress corrosion cracking of the mild steel used in the 10- and 14-ton depleted UF 6 storage cylinders has not been reported. However, SCC in the bronze one-inch valves used in the cylinders has occurred.

\section{5.a. Packing (Bonnet) nuts}

Stress corrosion cracking can occur under ambient conditions and has been identified in the packing nuts on the bronze one-inch valves used in the 10- and 14-ton mild steel depleted $\mathrm{UF}_{6}$ storage cylinders. ${ }^{20-25}$ SCC has also been seen on the port caps of the valves. ${ }^{25}$ SCC in valve packing nuts may be caused from inconsistencies in machining, improper or no stress relieving practice and/or excessive stress while in service. Packing nuts have failed from SCC while being stored in a storage bin prior to being used in service. ${ }^{25}$ 
The cylinder plug (CDA Alloy $\mathrm{C} 61300$ ) is stress relieved at $800^{\circ} \mathrm{F}$ for a minimum of one hour after machining. ${ }^{3}$ The packing nut for the valve (CDA Alloy C63600) is stress relieved at $700^{\circ} \mathrm{F}$ for a minimum of one hour after machining. ${ }^{3}$ A stress relief of the bronze alloy bar stock prior to machining will not eliminate SCC in the packing nuts. Stress relieving should be conducted after machining of the packing nuts such that the residual stresses are reduced from the machining operation.

Some of the failures of the valve packing nuts may have been caused by stress created from tightening the packing nut. The packing nuts are torqued initially when the cylinder is filled with depleted $\mathrm{UF}_{6}$. If the valve begins to leak, the packing nut may be retightened to stop the leak. The torque applied should be a minimum amount required to stop the leak but shall not exceed $100 \mathrm{ft}-1 \mathrm{~b} .^{3}$ Valves that require more than $100 \mathrm{ft}-1 \mathrm{~b}$ retorque to stop leakage shall not be heated. ${ }^{3}$

A laboratory study conducted in 1976 found a torque of $30 \mathrm{ft}-\mathrm{lbs}$ will provide an adequate seal for one-inch valves. ${ }^{27}$ However, after a heating-cooling cycle, the valves failed a leak test. A torque value of $120 \mathrm{ft}$-lbs was recommended for one-inch valves regardless of the valve temperature cycle. ${ }^{27}$ A study conducted in 1989 on cracked one inch packing nuts found that 50 to $75 \mathrm{ft}-\mathrm{lbs}$ torque will seal the packing assembly. ${ }^{24}$

The thermal cycling of the 10- and 14-ton mild steel depleted $\mathrm{UF}_{6}$ storage cylinders will cause the Teflon packing rings to relax, thereby lowering the torque required to remove the packing nut. ${ }^{27}$ The Teflon packing rings found in valves with cracked packing nuts have been extruded after experiencing multiple heating cycles. ${ }^{21}$ Extrusion of the Teflon packing rings has been found in many of the failed one-inch valves used in the cylinders.

\subsection{Mechanical Damage}

The 10- and 14-ton mild steel storage cylinders are often damaged inadvertently during routine handling. Handling of the cylinders can cause damage to the body of the cylinder, as well as the lifting lugs. Damage to the body of the cylinder may lead eventually to a breach.

\section{6.a. Cylinder impingement (dents)}

The 10- and 14-ton mild steel depleted $\mathrm{UF}_{6}$ storage cylinders may have been moved several times since they were filled originally. Moving the cylinders creates the possibility of causing inadvertent damage to the cylinders. For instance, lifting lugs of a cylinder have been found to impinge on adjacent cylinders. ${ }^{2,14}$

The investigation of the 4 breached cylinders at K-25 found that the breaches in two of the cylinders and one found at PGDP were caused by an impact from a lifting lug of an adjacent cylinder. ${ }^{14}$ The two breaches discovered at PORTS were caused by mechanical 
damage to the cylinders. ${ }^{2}$ The report on the breached cylinders stated that the holes in these cylinders may have taken several years to develop. "The initial small crack in Cylinder 114951 is believed to have been through-wall (fully penetrating the wall thickness), allowing the environment to begin hole growth immediately. However, the initial crack in Cylinder 116797 is believed to have been only partially through-wall, requiring external corrosion or mechanically-induced crack growth to complete the through-wall breach. ${ }^{14}$

A literature review of the impact strength of the mild steel used in the 10- and 14-ton depleted $\mathrm{UF}_{6}$ storage cylinders has been conducted. ${ }^{28}$ The review was conducted to show the ductile-to-brittle transition temperatures of the A285 and A516 mild steels used in the cylinders. The information was to be used to help determine the conditions under which the cylinders could be moved.

"Because of the poor impact resistance in the trans rolling direction of the thin-wall cylinder steels, fractures have been encountered due to accidental impact of the lifting lugs of an adjacent cylinder near welds and stiffening rings during handling. These failures were mechanical, not chemical, in origin. However, fractures of this type, if undetected, can result in the initiation of chemical reactions which, over time, will produce holes such as those found in the two tails cylinders at PORTS. While external electrochemical crevice corrosion at a crack that only partially penetrates the wall is capable of completing the penetration, it is not believed that this was necessary in the two cases under investigation; i.e., the cracks from the impacts completely penetrated the wall at the time of stacking." ${ }^{2}$

\section{6.b. Lifting lugs}

A magnetic particle inspection (MPI) of 510 mild steel depleted $\mathrm{UF}_{6}$ storage cylinders in the late 1980's and early 1990's indicated that $24 \%$ (122) of the cylinders examined had cracks at the lifting lug welds. ${ }^{29}$ The cracks may have been caused by a poor fit between the lifting lug and stiffening ring on the cylinder and/or improper weld practices. $^{29}$

\section{6.c. Stiffening rings}

During the investigation of the breached cylinders at PORTS, the stiffening rings on the 480 type 14-ton cylinders were found to contain water and were difficult to inspect. ${ }^{2}$ The 480 type cylinders have a U-channel type stiffening ring. These cylinders have void areas inside the stiffening rings that cannot be visually inspected. When these "U' channel stiffening rings are dented or torn by mechanical damage, water may enter and cause corrosion to occur over time. To date, the amount of corrosion in these cylinders in not known. 


\section{CONCLUSIONS}

A literature review of corrosion in the 10- and 14-ton mild steel depleted $\mathrm{UF}_{6}$ storage cylinders was conducted. The following conclusions can be made from the results of that review.

- General external corrosion occurs at a rate of about 1 to 2 mpy $(0.001$ to 0.002 " per year). A rate of up to about 5 mpy was found in the $48 \mathrm{G}$ type cylinders.

- Under normal storage conditions, general internal corrosion by the depleted $\mathrm{UF}_{6}$ is negligible.

- Crevice corrosion is found along the cylinder/saddle interface due to the retention of water in this area. The cylinder wall thickness was found to be as low as 0.140 " in this area.

- Crevice corrosion is found at the cylinder/skirt interface on the older cylinders that have a mild steel skirt due to the lack of water drainage in this area. A minimum wall thickness of $0.200^{\prime \prime}$ has been found in this area.

- Crevice corrosion occurs at the head of the cylinders behind the stainless steel cylinder I.D. nameplate. About 35 to 45 mils of accelerated corrosion of the mild steel occurs behind the nameplate.

- Galvanic corrosion occurs where the stainless steel cylinder I.D. nameplates are tack welded to the mild steel cylinder. The mild steel corrodes preferentially to the nameplate. This may cause the nameplate to become detached from the cylinder, which may cause difficulties in cylinder identification and monitoring.

- Stress corrosion cracking has been found in the packing nuts of the one-inch bronze valves used in the cylinders. This can be controlled with proper heat treatment practices and proper assembly procedures.

- Routine handling can cause mechanical damage to the cylinders that may lead to a breach with subsequent accelerated corrosion of the mild steel due to attack from HF and other $\mathrm{UF}_{6}$ hydrolysis by-products. 


\section{REFERENCES}

1. "Uranium Hexafluoride Tails Storage Cylinders," M.L. Glenn, KY-657, June 1974.

2. "Investigation of Breached Depleted UF 6 Cylinders," E.J. Barber, et al., POEF-2086, ORNL/TM-11988, September 1991.

3. "Uranium Hexafluoride-Packaging for Transport, ANSI N14.1-1990," American National Standard for Nuclear Materials, American National Standards Institute, June 1990.

4. "Uranium Hexaflouride: A Manual of Good Handling Practices," ORO-651 (Rev. 6) DE91015811, Analysas Corporation, Oak Ridge, Tennessee, October 1991.

5. "The Ultimate Disposition of Depleted Uranium," T. R. Lemons, Uranium Hexafluoride Handling Second International Conference Proceedings, October 1991, pages 123 - 129.

6. The Electrochemistry of Corrosion, D.L. Piron, National Association of Corrosion Engineers, Houston, Texas, 1991.

7. Corrosion Engineering, Third Edition, M.G. Fontana, McGraw-Hill Book company, New York, 1986.

8. Corrosion Handbook, edited by Herbert H. Uhlig, John Wiley \& Sons, Inc., New York, 1955.

9. "Evaluation of Ultrasonic Thickness Measurements of UF 6 Tails Cylinders, " M. Lykins and A. Edler, POEF-323-94-42, December 1994.

10. "Remaining Life of Uranium Hexafluoride Tails Storage Cylinders," J.H. Alderson, KY/L-1482, April 1988.

11. "Preliminary Investigation of Steel Compatibility with Potential Materials of Construction for UF $_{6}$ Cylinder Chocks," S.J. Pawel, et al., K/TCD-1057, December 1992.

12. "UF 6 Storage Cylinder Refurbishment Study-An Analysis of Coating Alternatives, "KTATator, Inc. Consultants, E. Bud Senkowski, EBS/DSL:WW, JN MD0005, June 1994.

13. "Aspects of Uranium Chemistry Pertaining To UF ${ }_{6}$ Cylinder Handling," R.L. Ritter and E.J. Barber, Uranium Hexafluoride Handing Second International Conference Proceedings, October 1991, pages 3 - 7. 


\section{REFERENCES (continued)}

14. "Investigation of Breached Depleted UF 6 Cylinders at the K-25 Site," E.J. Barber, et al., K/ETO-155, ORNL/TM-12840, October 1994.

15. "Report on Ultrasonic Wall Integrity Assessment, " H.E. Philpot, internal correspondence to V.S. Newman, February 1995.

16. "Preliminary Inspection of Two 14-Ton Cylinders," R. Dorning, POEF-423-92-48, February 1992.

17. "Use of Metallographic Replicas to Characterize Corrosion of UF 6 Cylinders," M. C. Rao, et al., internal correspondence to V. S. Newman, May 1995.

18. "Corrosion Monitoring in the $\mathrm{UF}_{6}$ Cylinder Yards at the Oak Ridge K-25 Site: FY 1994 Report," M. Rao, et al., October 1994.

19. . "Failure Analysis of One-Inch Rego Cylinder Valve," S.L. Fout, GAT-521-85-166, August 1985.

20. "Failure Analysis of Fractured One Inch Bonnet Nut," J.C. Dikeman, POEF-323-94-41, December 1994.

21. "Examination of Two One-Inch Cylinder Valves," R.E. Dorning, POEF-532-89-208, August 1989.

22. "Failure Analysis of a One-Inch Cylinder Valve Bonnet Nut," S.L.Fout, POEF-532-87164, June 1987.

23. "Failed One-Inch Packing Nut From The Low Assay Withdrawal Station, " M.L. Lykins, POEF-323-95-05, February, 1995.

24. "Cracking of 1-Inch $\mathrm{UF}_{6}$ Cylinder Valve Packing Nuts: The Effects of Packing Nut Torque on Stem Leakage and Packing Nut Stress Due to Thermal Expansion of the PTFE Stem Seal Rings," S.J. Davis, D.E. Underwood, KY/L-1549, August 1989.

25. "Examination of Three Failed UF 6 Cylinder Valve Bonnet Nuts (QA-329-28, 32 and 33)," A.D. Monokandilos, GAT-523-77-43, February 1977.

26. "Bonnet Nut Torque Values for $3 / 4$-and One-Inch $\mathrm{UF}_{6}$ Cylinder Valves," L.A. Zonner, S.D. Wamsley, GAT-523-76-55, March 1976. 


\section{REFERENCES (continued)}

27. "Torque Testing of Five-Inch and Ten-Ton Cylinder Valve Stems," J.L. Cannon, L.E. Storms, GAT-523-74-28, March 1974.

28. "Ductile-to-Brittle Transition Temperatures of A285 and A516 Mild Steel Used in the DUF, Cylinders," M.L. Lykins, POEF-38-343-95-38, June 1995.

29. "Cracked Lifting Lug Welds on Ten-Ton Cylinders," R.E. Dorning, POEF-T-3566, August 1991. 